\title{
HUBUNGAN PERAN PETUGAS KESEHATAN DAN PROMOSI SUSU FORM ULA TERHADAP PEMBERIAN ASI EKSKLUSIF PADA IBU MENYUSUI DI WILAYAH KERJA PUSKESMAS HARAPAN RAYA KOTA PEKANBARU 2018
}

\author{
ARM ONI SUCI DEWI ${ }^{1}$, AYU GUSTIWARN I ${ }^{2}$, RIKA SRI WAHYUN I ${ }^{2}$ \\ Akademi Kebidanan Internasional Pekanbaru \\ Email : armonisuci@yahoo.com
}

\begin{abstract}
Abstrak
ASI Eksklusif adalah pemberian ASI saja selama 6 bulan kehidupan pertama bayi tanpa tambahan cairan lain seperti susu formula, jeruk, madu, air putih dan tanpa tambahan makanan padat seperti pisang, bubur susu, biskuit. Faktor yang mempengaruhi keberhasilan dan kegagalan pemberian ASI Eksklusif ini salah satunya adalah peran dari petugas kesehatan dan promosi susu formula. Penelitian ini bertujuan untuk mengetahui hubungan peran petugas kesehatan dan promosi susu formula terhadap pemberian ASI Eksklusif pada ibu menyusui di Wilayah Kerja Puskesmas Harapan Raya Pekanbaru Tahun 2018. Jenis penelitian adalah kuantitatif dan desain analitik dengan pendekatan cross sectional. Penelitian dilakukan di W ilayah Kerja Puskesmas H arapan Raya pada bulan M aret - A pril Tahun 2018. Populasi penelitian ini ialah seluruh ibu yang memiliki bayi usia 6-12 bulan di Wilayah Kerja Puskesmas H arapan Raya Pekanbaru sebanyak 2.494 orang, sampel sebanyak 96 responden dengan metode pengambilan sampel kuota sampling. Instrumen penelitian ini menggunakan kuesioner dan teknik penelitian ini menggunakan data primer dan data sekunder. Berdasarkan hasil penelitian bahwa ibu yang memiliki bayi Di Wilayah Kerja Puskesmas Harapan Raya Pekanbaru minoritas memberikan ASI Eksklusif sebesar 47 (49\%) dan mendapatkan peran petugas kesehatan sebesar 35 (36,5\%) dan tidak mendapatkan promosi susu formula sebesar 36 (37,5\%). sehingga dapat disimpulkan tidak ada hubungan antara peran petugas kesehatan terhadap pemberian ASI Eksklusif ( $P$ Value $0,563)$ dan ada hubungan antara promosi susu formula terhadap pemberian ASI Eksklusif ( $P$ Value0,040). Diharapkan bagi tenaga kesehatan untuk lebih meningkatkan pemberian informasi mengenai ASI Eksklusif dan manfaatnya dengan memberikan penyuluhan atau pendekatan lainnya.
\end{abstract}

Kata kunci : ASI Eksklusif, Peran petugas kesehatan, Promosi Susu Formula

Abstract

Exclusive breastfeeding is breastfeeding alone for the first 6 months of life without any additional fluids such as formula, oranges, honey, water and without additional solid foods such as bananas, milk porridge, biscuits. Factors affecting the success and failure of exclusive breastfeeding is one of them is the role of health officers and the promotion of infant formula. This study aims to determine the relationship between the role of health officers and the promotion of formula milk to exclusive breastfeeding in breastfeeding mothers in the W ork Area of Harapan Raya Pekanbaru Health Center Year 2018. The research type is quantitative and analytic design with cross sectional approach. The study was conducted in Harapan Raya Public Health W orking Area in M arch - A pril of 2018. The population of this study is all mothers who have infants aged 6-12 months in Harapan Raya Pekanbaru Health Center Working Area as many as 2,494 people, the sample of 96 respondents with quota sampling method sampling. The instrument of this research using questionnaires and techniques of this study using primary data and secondary data. Based on the result of the research, the mother who has babies in the work area of H arapan Raya Pekanbaru M inority H ealth Center gave exclusive breast feeding of $47(49 \%)$ and got the health worker role $35(36,5 \%)$ and did not get formula promotion equal to $36(37,5 \%)$. so it can be concluded there is no relation between the role of health officer to exclusive breastfeeding $(P$ Value 0,563$)$ and there is relationship between promotion of formula milk to Exclusive Breast Feeding ( $P$ Value 0,040). It is hoped for health workers to further improve the provision of information on Exclusive Breast M ilk and its benefits by providing counseling or other approaches.

Keyword : Exclusive breastfeeding, the role of health workers, promotion of formula milk

\section{PENDAHULUAN}

Air Susu Ibu (ASI) merupakan makanan yang ideal bagi pertumbuhan neonatus, hal ini disebabkan karena ASI merupakan suatu emulsi lemak dalam larutan protein, laktose dan garam organik yang disekresi oleh kedua belah kelenjar payudara ibu, yang berguna sebagai makanan utama bagi bayi (N ugroho, 2011). 
Air Susu Ibu Eksklusif adalah pemberian ASI kepada bayi, tidak ada cairan atau makanan padat lain diberikan kecuali vitamin, mineral dan obat dalam bentuk oralit, tetes, dan sirup Menurut data World Breastfeeding Trends Initiative 2012, Indonesia berada di peringkat yang sangat rendah dalam mendukung pemberian A Sl eksklusif (W orld H ealth Organization, 2014).

U paya untuk mendukung peningkatan pemberian ASI Eksklusif dapat dilihat dari telah dikeluarkannya berbagai pengakuan atau kesepakatan baik yang bersifat global maupun nasional yang bertujuan melindungi, mempromosi, dan mendukung pemberian ASI. Dengan demikian, diharapkan setiap bayi diseluruh dunia memperoleh haknya mendapatkan ASI. Sesuai dengan Sustainable Development Goals (SDGs) ke-3 target ke-2 yaitu pada tahun 2030, seluruh negara berusaha untuk menurunkan Angka Kematian Neonatal (AKN) setidaknya hingga 12 per 1.000 Kelahiran H idup.

Menurut Peraturan Pemerintah (PP) Nomor 33 tahun 2012 pasal 6 target capaian ASI Eksklusif di Indonesia adalah 100\%, dan Undang-Undang (UU) Republik Indonesia Nomor 36 Tahun 2009 tentang Kesehatan pasal 128 ayat 1 yang berbunyi: "setiap bayi berhak mendapatkan Air Susu Ibu Eksklusif sejak dilahirkan selama 6 (enam) bulan, kecuali atas indikasi medis". Selanjutnya pelayanan yang mendukung pemberian Air Susu Eksklusif juga tercantum pada Peraturan Pemerintah (PP) Republik Indonesia Nomor 61 tahun 2014 tentang kesehatan reproduksi pasal 17 ayat 1. ASI Eksklusif juga termasuk kedalam Intervensi spesifik dalam kegiatan atau tindakan untuk mensukseskan program pemerintah 1000 hari pertama kehidupan.

Salah satu faktor yang menyebabkan seorang ibu tidak memberikan ASI kepada bayinya disebabkan oleh meningkatnya promosi susu kaleng sebagai pengganti ASI, sehingga promosi susu formula dapat dikatakan sebagai penyebab menurunnya jumlah bayi yang mendapat ASI secara Eksklusif (Siregar, 2004). M enurut data sementara SD KI tahun 2007 angka pemberian susu formula sebesar 27,9\% (W ibisono, 2008). Pada tahun 2010 pemberian susu formula mengalami peningkatan yang pesat yaitu sebesar 71,3\% (Riset kesehatan dasar, 2010).

Produk susu formula dipromosikan melalui iklan di media sosial dan promosi di pertokoan. Produsen susu formula juga aktif berpromosi di rumah sakit serta melalui petugas pelayanan kesehatan, seperti dokter, perawat, bidan dan paramedis lainnya. Produsen dan petugas kesehatan tersebut tidak mematuhi aturan kode etik internasional tentang promosi susu formula, produsen mempromosikan susu formula kepada petugas kesehatan, sedangkan petugas kesehatan memberikan susu formula tersebut kepada ibu-ibu yang baru melahirkan (Ety, 2010). Berdasarkan monitoring yang dilakukan oleh Badan Kerja Peningkatan Penggunaan ASI (BKPP-ASI), banyak rumah sakit bersalin yang tidak mendukung pmberian ASI. Beberapa kasus bayi yang baru dilahirkan dipisahkan dari ibunya dengan beberapa alasan, yang seharusnya bayi baru lahir di berikan IM D agar refleksnya berkembang dan produksi susu ibunya meningkat. pelanggaran lain yang dibuat pihak rumah sakit bersalin adalah pemberian sampel susu kaleng secara gratis pada pasien. Ibu yang baru pulang dari Rumah Sakit Bersalin diberikan oleh-oleh susu formula gratis, sehingga mengakibatkan semakin banyak ibu-ibu yang tidak percaya dengan manfaat dari kandungan ASI akibat pengaruh iklan yang mengidealkan kandungan zat gizi terdapat dalam susu formula (M entri koordinator bidang ekonomi dan kesejahteraan rakyat, 2007). 
Solusi pemerintah terhadap meningkatnya promosi susu formula di masyarakat adalah dengan mengeluarkan PP nomor 33/2012 tentang Pemberian ASI Eksklusif yang menegaskan bahwa tenaga dan fasilitas kesehatan yang memberikan susu formula harus mentaati beberapa ketentuan termasuk dilarang melakukan kegiatan promosi (Pramudiarja, 2012). Pemerintah juga mengatur pemasaran pengganti ASI melalui Keputusan Mentri Kesehatan Nomor 237/M enkes/SK/IV/1997 yang di rujuk dari The International Code Of Marketingn Of Breastmilk Substitutes yang dikeluarkan WHO pada tahun 1981 yang menjelaskan bahwa untuk produk pengganti ASI sebagai menu utama bayi usia 0-6 bulan, dihimbau untuk tidak melakukan promosi atau publikasi dalam bentuk apapun. Peraturan tersebut telah berjalan, namun promosi pemasaran produk susu formula dilakukan secara berlebihan hingga melanggar KODE WHO, karena promosi tersebut terjadi pada semua media, langsung ke konsumen, dan mencapai jajaran petugas kesehatan (AIM I, 2010).

Berdasarkan hasil data dari Dinas Kesehatan Kota Pekanbaru didapatkan Puskesmas Umban Sari (37,5\%), Puskesmas Rumbai Bukit (46,1\%), dan Puskesmas Harapan Raya (59,7\%) dengan cakupan pemberian ASI Eksklusif paling rendah. Berdasarkan latar belakang diatas dan hasil survey awal kepada 7 responden, didapatkan ada 5 responden yang tidak memberikan ASI Eksklusif kepada bayinya. Oleh karena itu peneliti tertarik untuk melakukan penelitian dengan judul "Hubungan Peran Petugas Kesehatan Dan Promosi Susu Formula Terhadap Pemberian ASI Eksklusif Pada Ibu M enyusui Di W ilayah Kerja Puskesmas Harapan Raya Kota Pekanbaru Tahun 2018".

\section{METODE PENELITIAN}

Jenis penelitian ini menggunakan jenis Kuantitatif dengan desain Analitik dengan pendekatan Cross Sectional . Penelitian ini bertujuan untuk mengetahui Hubungan Peran Petugas Kesehatan Dan Promosi Susu Formula Terhadap Pemberian ASI Eksklusif Pada Ibu Menyusui Di Wilayah Kerja Puskesmas Harapan Raya Kota Pekanbaru Tahun 2018. Populasi adalah keseluruhan objek penelitian atau objek yang diteliti (Notoatmojo, 2005). Populasi pada penelitian ini adalah ibu-ibu yang mempunyai bayi berusia 6 hingga 12 bulan Di Wilayah Kerja Puskesmas H arapan Raya Tahun 2018 sebanyak 96 responden. Pengumpulan data dilakukan dengan cara mengisi kuesioner berupa tabel ceklist.

\section{HASIL PENELITIAN DAN PEMBAHASAN}

1. Analisi Univariat

Tabel 1.1 Distribusi Fekuensi Peran Petugas Kesehatan di W ilayah Kerja Puskesmas Harapan Raya Tahun 2018

\begin{tabular}{|c|c|c|c|}
\hline No & Peran Petugas Kesehatan & $\begin{array}{c}\text { Frekuensi } \\
\text { (N) }\end{array}$ & $\begin{array}{c}\text { Persentase } \\
\text { (\%) }\end{array}$ \\
\hline 1 & Tidak Berperan & 61 & $64 \%$ \\
\hline 2 & Berperan & 35 & $37 \%$ \\
\hline & Total & 96 & $100 \%$ \\
\hline
\end{tabular}

Sumber : A nalisis Data Primer 2018

Berdasarkan tabel 4.1 dapat disimpulkan bahwa dari 96 responden sebanyak 61 responden (64\%) tidak mendapatkan peran petugas kesehatan, dan ada 35 reponden (37\%) mendapatkan peran petugas kesehatan. 
Tabel 1.2 Distribusi Fekuensi Promosi Susu Formula di Wilayah Kerja Puskesmas H arapan Raya Tahun 2018

\begin{tabular}{|c|c|c|c|}
\hline No & Promosi Susu Formula & $\begin{array}{c}\text { Frekuensi } \\
\text { (N) }\end{array}$ & $\begin{array}{c}\text { Persentase } \\
\text { (\%) }\end{array}$ \\
\hline 1 & Tidak A da Promosi & 36 & $38 \%$ \\
\hline 2 & Ada Promosi & 60 & $63 \%$ \\
\hline & Total & 96 & $100 \%$ \\
\hline
\end{tabular}

Sumber : A nalisis Data Primer 2018

Berdasarkan tabel 4.2 dapat disimpulkan bahwa dari 96 responden sebanyak 36 responden (38\%) tidak mendapatkan promosi susu formula, dan ada 60 reponden (63\%) mendapatkan promosi susu formula. Tabel 1.3 Distribusi Fekuensi Pemberian ASI Eksklusif di Wilayah Kerja Puskesmas H arapan Raya Tahun

\begin{tabular}{|c|c|c|c|}
\hline No & Pemberian ASI Eksklusif & $\begin{array}{l}\text { Frekuensi } \\
\text { (N) }\end{array}$ & $\begin{array}{l}\text { ersentase } \\
\text { (\%) }\end{array}$ \\
\hline 1 & Tidak ASI Eksklusif & 49 & $51 \%$ \\
\hline 2 & ASI Eksklusif & 47 & $49 \%$ \\
\hline & Q Total & 96 & $100 \%$ \\
\hline
\end{tabular}

Sumber : A nalisis Data Primer 2018

Berdasarkan tabel 4.3 dapat disimpulkan bahwa dari 96 responden sebanyak 49 responden (51\%) tidak memberikan ASI Eksklusif, dan ada 47 reponden (49\%) memberikan ASI Eksklusif.

\section{Analisa Bivariat}

Tabel 2.1 Hubungan Peran Petugas Kesehatan Terhadap Pemberian ASI Eksklusif di W ilayah Kerja Puskesmas H arapan Raya Tahun 2018

\begin{tabular}{|c|c|c|c|c|c|c|c|c|}
\hline \multirow{3}{*}{ No } & \multirow{3}{*}{$\begin{array}{l}\text { Peran petugas } \\
\text { Kesehatan }\end{array}$} & \multicolumn{4}{|c|}{ Pemberian ASI Eksklusif } & & & \multirow{3}{*}{$P V A L U E$} \\
\hline & & \multicolumn{2}{|c|}{ ASI eksklusif } & \multicolumn{2}{|c|}{$\begin{array}{l}\text { Tidak ASI } \\
\text { Eksklusif }\end{array}$} & & & \\
\hline & & $\mathbf{N}$ & $\%$ & $\mathbf{N}$ & $\%$ & $\mathrm{~N}$ & $\%$ & \\
\hline 1 & Berperan & 19 & $40 \%$ & 16 & $33 \%$ & 35 & $100 \%$ & \\
\hline 2 & Tidak berperan & 28 & $60 \%$ & 33 & $67 \%$ & 61 & $100 \%$ & 0,563 \\
\hline & Total & 47 & $49 \%$ & 49 & $51 \%$ & 96 & $100 \%$ & \\
\hline
\end{tabular}

Sumber : A nalisis Data Primer 2018

Dapat diketahui dari 35 responden yang mendapatkan peran petugas kesehatan diantaranya 19 responden (40\%) memberikan ASI Eksklusif dan 16 responden (33\%) tidak memberikan ASI Eksklusif, dan dari 61 responden yang tidak mendapatkan peran petugas kesehatan diantaranya 28 responden (60\%) memberikan ASI Eksklusif dan 33 responden (67\%) tidak memberikan ASI Eksklusif. Untuk mengetahui chi-square dilakukan dengan menggunakan program SPSS. H ipotesis diterima apa bila $P$ Value 0,05 . Berdasarkan analisis 
Hubungan Peran Petugas Kesehatan terhadap Pemberian ASI Eksklusif di W ilayah Kerja Puskesmas Harapan Raya Pekanbaru Tahun 2018 melalui uji chi-square didapatkan $P$ Value> 0,05. Jadi Ho gagal ditolak, sehingga dapat disimpulkan bahwa tidak adanya H ubungan Peran Petugas Kesehatan Terhadap Pemberian ASI Eksklusif di W ilayah Kerja Puskesmas H arapan Raya Tahun 2018.

Tabel 2.2 H ubungan Promosi Susu Formula Terhadap Pemberian ASI Eksklusif di Wilayah Kerja Puskesmas H arapan Raya Tahun 2018

\begin{tabular}{|c|c|c|c|c|c|c|c|c|}
\hline \multirow{3}{*}{ No } & \multirow{3}{*}{$\begin{array}{c}\text { Promosi Susu } \\
\text { Formula }\end{array}$} & \multicolumn{4}{|c|}{ Pemberian ASI Eksklusif } & \multirow{2}{*}{\multicolumn{2}{|c|}{ TOTAL }} & \multirow{3}{*}{ PVALUE } \\
\hline & & \multicolumn{2}{|c|}{ ASI eksklusif } & \multicolumn{2}{|c|}{$\begin{array}{l}\text { Tidak ASI } \\
\text { Eksklusif }\end{array}$} & & & \\
\hline & & IV & $\%$ & $\mathrm{~N}$ & $\%$ & $\mathrm{~N}$ & $\%$ & \\
\hline 1 & Ada Promosi & 24 & $51 \%$ & 36 & $74 \%$ & 60 & $100 \%$ & \\
\hline 2 & Tidak ada Promos & 23 & $49 \%$ & 13 & $27 \%$ & 36 & $100 \%$ & 0,040 \\
\hline & Total & 47 & $49 \%$ & 49 & $51 \%$ & 96 & $100 \%$ & \\
\hline
\end{tabular}

Sumber : A nalisis Data Primer 2018

Dapat diketahui dari 60 responden yang terpapar promosi susu formula diantaranya 24 responden (51\%) memberikan ASI Eksklusif dan 36 responden (74\%) tidak memberikan ASI Eksklusif, dan dari 36 responden yang tidak terpapar promosi susu formula diantaranya 23 responden $(49 \%)$ memberikan ASI Eksklusif dan 13 responden (27\%) tidak memberikan ASI Eksklusif. Untuk mengetahui chi-square dilakukan dengan menggunakan program SPSS. H ipotesis diterima apa bila $P$ Value $<0,05$.

Berdasarkan analisis Hubungan Peran Petugas Kesehatan terhadap Pemberian ASI Eksklusif Di W ilayah Kerja Puskesmas H arapan Raya Pekanbaru Tahun 2018 melalui uji chi-square didapatkan $P$ Value< 0,05. Jadi H a diterima, sehingga dapat disimpulkan bahwa A da H ubungan Promosi Susu Formula Terhadap Pemberian ASI Eksklusif di Wilayah Kerja Puskesmas H arapan Raya Tahun 2018.

\section{Pembahasan}

\section{A. Peran Petugas Kesehatan}

Berdasarkan hasil penelitian yang telah peneliti lakukan Di Wilayah Kerja Puskesmas Harapan Raya Pekanbaru diperoleh mayoritas responden tidak mendapatkan peran petugas kesehatan sebanyak 61 orang $(63,5 \%)$.

Peran merupakan perilaku individu yang diharapkan sesuai dengan posisi yang dimiliki. Peran yaitu suatu pola tingkah laku, kepercayaan, nilai, dan sikap yang diharapkan dapat menggambarkan perilaku yang seharusnya diperlihatkan oleh individu pemegang peran tersebut dalam situasi yang umumnya terjadi (Sarwono, 2012). Sedangkan Petugas kesehatan menurut Undang-Undang Republik Indonesia Tentang Kesehatan No. 36 Tahun 2014 merupakan setiap orang yang mengabdikan diri dalam bidang 
kesehatan serta memiliki pengetahuan dan keterampilan melalui pendidikan di bidang kesehatan untuk jenis tertentu yang memerlukan kewenangan dalam melakukan upaya kesehatan. Sehingga peran petugas kesehatan merupakan tingkah laku atau sikap seorang petugas kesehatan dalam memberikan informasi, edukasi dan tindakan yang sesuai untuk pasien.

Peneliti berasumsi bahwa ibu tidak merasakan peran petugas kesehatan karena sebagian besar ibu sudah melahirkan lebih dari satu kali sehingga petugas kesehatan merasa tidak perlu memberikan informasi lagi mengenai ASI Eksklusif yang mengakibatkan ibu tidak memberikan ASI Eksklusif karena adanya anggapan bahwa bayi masih merasa lapar jika hanya diberikan ASI saja, dan memberikan tambahan air putih dan madu setelah bayi diberikan ASI juga menjadi salah satu alasan ibu tidak memberikan ASI secara Eksklusif.

\section{B. Promosi Susu Formula}

Berdasarkan hasil penelitian yang telah peneliti lakukan Di Wilayah Kerja Puskesmas Harapan Raya Pekanbaru diperoleh mayoritas responden mendapatkan Promosi Susu Formula sebanyak 60 orang $(62,5 \%)$, dan yang tidak mendapatkan promosi susu formula sebanyak 36 orang (37,5\%).

Promosi merupakan bentuk dari komunikasi pemasaran dalam bentuk serangkaian aktivitas-aktivitas yang menyeluruh untuk memasarkan sesuatu baik untuk tujuan finansial maupun finansial (Shimp,T.A, 2003).Susu formula adalah cairan yang berisi zat yang mati. Didalamnya tidak ada sel hidup seperti sel darah putih, zat pembunuh bakteri, antibody, enzim, hormon, dan juga tidak mengandung faktor pertumbuhan (Roesli, 2009).

Promosi susu formula merupakan suatu penyebarluasan informasi produk susu formula. Terdapatnya promosi susu formula di sarana pelayanan kesehatan khususnya di tempat persalinan mempunyai pengaruh langsung terhadap pemberian ASI Eksklusif.

Untuk pembatasan susu formula, Menteri Kesehatan (MenKes) menyebutkan bahwa tenaga kesehatan dilarang menerima dan mempromosikan susu formula. $\mathrm{H}$ al ini telah dijelaskan pada Pasal 17 ayat (1) PP No. 33 Tahun 2012 Tentang Pemberian Air Susu Ibu Eksklusif, setiap tenaga kesehatan dilarang memberikan susu formula bayi dan/atau produk bayi lainnya yang dapat menghambat program pemberian ASI Eksklusif kecuali dalam hal diperuntukkan sebagaimana dimaksud dalam pasal 15. Berdasarkan Peraturan Pemerintah tersebut, seharusnya bayi mendapatkan ASI Eksklusif sejak lahir sampai usia 6 bulan.

Peneliti berasumsi bahwa masih banyaknya ibu yang mendapatkan promosi susu formula dapat dilihat dari hasil penelitian dikarenakan cara agen susu formula dalam memasarkan produknya kepada petugas kesehatan sangat menarik yang membuat petugas kesehatan semangat untuk memasarkannya produk susu formula kepada pasiennya sehingga banyak ibu mendapatkan promosi susu formula langsung dari petugas kesehatan. $\mathrm{H}$ al ini yang membuat ibu-ibu yakin untuk memberikan susu formula dan mengenyampingkan pemberian hanya ASI saja kepada banyinya selama 6 bulan pertama kehidupannya. 


\section{Pemberian ASI Eksklusif}

Berdasarkan hasil penelitian yang telah peneliti lakukan Di W ilayah Kerja Puskesmas Harapan Raya Pekanbaru diperoleh mayoritas responden tidak memberikan ASI Eksklusif sebanyak 49 orang (51\%).

ASI Eksklusif atau lebih tepat pemberian ASI secara Eksklusif adalah bayi yang hanya diberi ASI saja tanpa tambahan cairan lain seperti susu formula,jeruk,madu,air teh,air putih dan tanpa tambahan makanan padat seperti pisang, pepaya, bubur susu, biscuit, bubur nasi dan tim. Pemberian ASI secara Eksklusif ini dianjurkan untuk jangka waktu sampai 6 bulan.

Pemberian ASI Eksklusif pada 6 bulan pertama kehidupan sangat penting karena memberikan manfaat yang sangat besar bagi bayi sepanjang kehidupannya. Manfaat ASI Eksklusif tidak hanya dirasakan oleh bayi saja bahkan dirasakan oleh ibu juga.

Banyak ibu menyusui yang salah persepsi, salah mengerti arti ASI Eksklusif itu sendiri. Hal itu disebabkan karena pengaruh dari luar seperti dukungan keluarga, pengetahuan yang rendah dalam mendapatkan informasi untuk mendukung terlaksanakannya program ASI Eksklusif sehingga seringkali mereka memberikan makanan pendamping ASI ataupun susu formula sebelum waktunya. Untuk meningkatkan jumlah pemberian ASI Eksklusif maka dari itu diperlukan adanya usaha dalam meningkatkan informasi mengenai ASI Eksklusif selama sebelum kehamilan, saat hamil dan awal menyusui bayi secara bertahap serta mendalam mengenai ASI Eksklusif agar ibu mudah memahami dan mengerti arti bagaimana menyusui secara Eksklusif itu sebenarnya.

Peneliti berasumsi bahwa masih kurangnya pemberian ASI Eksklusif dikarenakan masih ada responden yang tidak memahami apa yang dikatakan dengan ASI Eksklusif, karena masih banyak responden yang tidak mendapatkan peran aktif petugas kesehatan mengenai manfaat ASI Eksklusif dan masih banyaknya responden yang mendapatkan promosi susu formula langsung dari petugas kesehatan. Banyaknya ibu yang tidak memberikan ASI Eksklusif kepada bayinya akan berdampak pada lambatnya penurunan AKB (Angka Kematian Bayi) di Indonesia meningkatnya status gizi buruk dan gizi kurang serta menurunnya kualitas sumber daya manusia.

\section{Hubungan Peran Petugas Kesehatan Terhadap Pemberian ASI Eksklusif}

Berdasarkan hasil penelitian yang telah peneliti lakukan Di Wilayah Kerja Puskesmas Harapan Raya dari 96 responden, mayoritas responden tidak mendapatkan peran petugas kesehatan sebanyak 61 orang (63,5\%). M enurut hasil uji statistik, didapatkan tidak adanya hubungan antara Peran Petugas Kesehatan terhadap pemberian ASI Eksklusif, hal ini bertolak belakang dengan hasil penelitian yang dilakukan oleh Muthmainnah Rasyid pada tahun 2015 yang berjudul Hubungan Pengetahuan Ibu dan Peran Petugas Kesehatan dengan Pemberian ASI Eksklusif, hasil penelitiannya menunjukkan bahwa peran petugas kesehatan yang baik dan kurang baik dapat memberikan pengaruh terhadap pemberian ASI Eksklusif kepada bayinya.

M enurut Peraturan pemerintah nomor 33 tahun 2012 tentang pemberian air susu ibu eksklusif pasal 8 ayat 3 menyebutkan bahwa dalam hal di daerah tertentu tidak terdapat dokter, penentuan ada 
atau tidaknya indikasi medis dapat dilakukan oleh bidan atau perawat sesuai dengan ketentuan peraturan perundang undangan. Namun hasil yang didapatkan bertolak belakang dengan Peraturan PerundangUndangan yang berlaku. Peneliti berasumsi bahwa hal ini tidak memiliki hubungan karena dari hasil penelitian didapatkan banyak responden yang tidak mendapatkan peranan aktif dari petugas kesehatan dikarenakan banyak ibu yang multipara, sehingga petugas kesehatan beranggapan tidak perlu memberikan informasi atau pun edukasi mengenai ASI Eksklusif.peneliti juga berasumsi adanya faktor lain yang berperan dalam pemberian ASI Eksklusif seperti faktor sosial budaya, faktor lingkungan, faktor dukungan keluarga, pengalaman sebelumnya dan lain sebagainya.

\section{E. H ubungan Promosi Susu Formula Terhadap Pemberian ASI Eksklusif}

Berdasarkan hasil penelitian yang telah peneliti lakukan di Wilayah Kerja Puskesmas Harapan Raya dari 96 responden, mayoritas responden ada mendapatkan promosi susu formula sebanyak 60 orang (62,5\%). Menurut hasil uji statistik, didapatkan ada hubungan antara promosi susu formula terhadap pemberian ASI Eksklusif, hal ini sejalan dengan hasil penelitian yang dilakukan oleh Siregar pada tahun 2014 bahwa frekuensi terpaparnya promosi susu formula memiliki hubungan yang bermakna terhadap pemberian ASI Eksklusif, namun hal ini bertolak belakang dengan hasil penelitian yang dilakukan oleh Fikri Ulil Albab pada tahun 2013 yang berjudul H ubungan Antara Promosi Susu Formula dengan Pengambilan Keputusan Dalam Pemberian ASI Eksklusif.

Saat ini produsen susu formula sangat gencar dalam mempromosikan produknya dengan berbagai teknik promosi yang dapat mempengaruhi konsumen antara lain melalui bentuk kemasan yang menarik, iklan, harga, serta hadiah. Promosi ASI Eksklusif tidak cukup kuat untuk menandingi promosi susu formula. Promosi susu formula tidak saja ditemukan di berbagai media elektronik maupun cetak bahkan promosi susu formula ditemukan juga dipelayanan kesehatan dalam bentuk kalender, jam dinding, pengukur tinggi badan, poster bahkan tawaran langsung oleh petugas kesehatan kepada pasien. Produsen sebagian besar masih berpegang pada peraturan lama yaitu batasan ASI eksklusif sampai empat bulan sehingga makanan pengganti ASI misalnya bubur susu, biskuit masih mencantumkan label untuk usia empat bulan ke atas (Soetjiningsih, 2001).

Petugas kesehatan yang terdapat pada tempat persalinan merupakan salah satu akses untuk keberhasilan program ASI Eksklusif. Ibu dan keluarga sangat membutuhkan dukungan dari petugas kesehatan dalam pemberian ASI Eksklusif, masyarakat akan mempercayai bahwa tindakan yang dilakukan oleh petugas kesehatan merupakan hal yang terbaik untuk bayi. Oleh karena itu seharusnya petugas kesehatan memberikan perilaku yang positif terhadap masyarakat berkaitan dengan pemberian ASI Eksklusif. Memberikan susu formula kepada bayi baru lahir tanpa indikasi atau menyarankan pemberiannya merupakan kekeliruan besar yang dilakukan oleh petugas kesehatan sehingga dapat mengubah persepsi masyarakat terhadap penggunaan susu formula. Peneliti berasumsi kemungkinan reponden tidak memberikan ASI Eksklusif kepada bayinya karena responden terpapar promosi susu 
formula, terlebih lagi promosi dilakukan oleh petugas kesehatan yang mengakibatkan ibu mengambil keputusan untuk tidak memberikan ASI secara Eksklusif kepada bayinya.

\section{KESIM PULAN}

Berdasarkan hasil penelitian mengenai Hubungan Peran Petugas Kesehatan dan Promosi Susu Formula Terhadap Pemberian ASI Eksklusif di Wilayah Kerja Puskesmas Harapan Raya Pekanbaru Tahun 2018 diperoleh kesimpulan sebagai berikut:

1. Dari 96 responden terdapat 61 reponden $(63,5 \%)$ yang tidak mendapatkan peran petugas kesehatan

2. Dari 96 responden terdapat 60 responden (62,5\%) yang mendapatkan promosi susu formula.

3. Dari 96 responden terdapat 49 reponden (51\%) yang tidak memberikan ASI Eksklusif kepada bayinya.

4. Tidak terdapat hubungan antara peran petugas kesehatan dan pemberian ASI Eksklusif.

5. Terdapat hubungan antara promosi susu formula dan pemberian ASI Eksklusif.

\section{DAFTAR PUSTAKA}

Ajeng, D wi Retrani, (2016). Hubungan peran petugas kesehatan dengan motivasi ibu dalam pemberian ASI eksklusif di Desa Wonorejo Kecamatan Kencong Kabupaten Jember [KTI] Jember : U niversitas Jember

A mbarwati, R.E., W ulandari, D. (2009). Asuhan Kebidanan Nifas. M itra Cendika Press. Yogyakarta

Amiruddin, R., Rostia, (2006). Promosi Susu Formula M enghambat Pemberian ASI Eksklusif di Kelurahan Pa-Baeng-Baeng Makasar Tahun 2006, Artikel IImiah, FKM U NHAS

Ari Setiani, (2011). Hubungan pengetahuan ibu tentang pemberian susu formula dengan praktek pemberian susu formula pada bayi usia 7-12 bulan di puskesmas ngemplak simongan [KTI] Semarang : A kademi Kebidanan A bdi Husada Semarang

Arifin, M Siregar. (2004). Pemberian ASI Eksklusif dan Faktor-Faktor yang M empengaruhinya. [skripsi]. M edan : Fakultas Kesehatan M asyarakat USU

Badan Penelitian dan Pengembangan Kesehatan. (2010). Riskesdas (2010). http://www. Litbang.depkes.go.id/sites/download/buku laporan/lapnas riskesdas2010 /Laporan_riskesdas_2010.pdf. Diakses 07 Januari 2018.

Depertemen Kesehatan RI, (2005), Manajemen Laktasi Buku Panduan Bagi Bidan dan Petugas Kesehatan di Puskesmas. Departemen Kesehatan RI di Jakarta.

Fikawati, S.dan Syafiq, A. (2003). Hubungan antara intermediate breasfeeding dan ASI Eksklusif 4 bulan. Jurnal kedokteran trisakti. Vol 22 (2).

Fikri Ulil Albab, (2013). Hubungan promosi susu formula dengan pengambilan keputusan keluarga dalam pemberian ASI eksklusif di wilayah kerja puskesmas arjasa kabupaten jember [skripsi]. Jember : IImu Keperawatan U niversitas Jember

N otoadmojo, Soekidjo.(2005). M etodologi Penelitian Kesehatan. Jakarta:Rineka Cipta

N otoadmojo. 2010). Metodologi Penelitian Kesehatan. Jakarta. Asdi M Mastya. 
Pramudiarja U. (2012). Mengulas PP AS/. Diakses : 30 April 2016. http://health.detik.com/read/2012/04/03/100136/1883596/775/kenapa-asieksklusif-wajib-diberikanselama-6-bulan.

Purwanti, hubertin, sri. (2004). Konsep penerapan ASI Eksk/usif. Jakarta : EGC

Pudjiadi, S. (2001). Bayiku Sayang: petunjuk Bergambar Untuk Merawat Bayi dan Jawaban atas 62 Pertanyaan yang M encemaskan. Jakarta: Fakultas K edokteran UI. Diakses tanggal 5 Februari 2018.

Riset Dinas Kesehatan Kota Pekanbaru. (2016). Jumlah bayi dan cakupan ASI SeKota Pekanbaru. Pekanbaru

Roesli, utami. (2007). Mengenal ASI eksk/usif. Jakarta : Trubus Agriwidya

Sentya putri, (2008). Faktor yang melatar belakangi pemberian asi eksklusif pada ibu menyusui di kelurahan padang bulan wilayah kerja puskesmas senapelan kecamatan senapelan [KTI] Pekanbaru : akademi kebidanan internasional pekanbaru

Siti M ulyani, Nina. (2013). AS/ dan Pedoman Ibu Menyusui. Nuha M edika, Yogyakarta.

Soetjiningsih. (1997). ASl petunjuk untuk petugas kesehatan. Jakarta : EGC

Staf Pengajar IImu Kesehatan Anak Fakultas Kesehatan U niversitas Indonesia (2005). I/mu kesehatan anak 3. Jakarta : INFOM EDIKA

Suririnah, (2004) Air Susu Ibu (ASI) memberi keuntungan ganda untuk ibu dan bayi. http://www.infoibu.com/mod.php?mod=publisher\&op=viewarticle\&artid=11. Tanggal 4 maret 2008

Syntia trie hermawatie, (2008). Karakteristik ibu yang tidak memberikan asi eksklusif di kelurahan tangkerang labuai kecamatan bukit raya [KTI] Pekanbaru : akademi kebidanan internasional pekanbaru.

Taufan Nugroho, Nurrezki, A.Md Keb, Desi Warnaliza, A.Md Keb, Wilis, A.M d Keb. (2014). Buku Ajar Asuhan Kebidanan 3 Nifas. N uha M edica, Yogyakarta.

Taufan Nugroho, (2011).ASI dan Tumor Payudara. Nuha M edica, Yogyakarta.

Tien Ihsani, (2011). Hubungan Promosi Susu Formula dan Faktor Lainnya Dengan Pemberian ASI Eksklusif Di Kota Solok Provinsi Sumatera Barat [Skripsi]. Depok : Peminatan Kebidanan Komunitas Fakultas Kesehatan M asyarakat U niversitas Indonesia.

Vinter. Tine and Elisabeth H elsing. (1997). Breasfeeding how to support succes. A pratical guide for health workers. World health organization regional office for Europe copenhagen. Diunggah 5 Januari 2018 